\title{
Absenteeism due to mental problems among employees in nursing
}

\author{
Brigita Jeretina', Katja Krt², Andrej Starc' \\ I Univesrity of Ljubljana, Faculty of Health Sciences, Zdravstvena pot 5, 1000 Ljubljana, Slovenia \\ 2 University Medical Centre Ljubljana, Clinic of Surgery, Zaloška cesta 7, 1000 Ljubljana, Slovenia \\ brigita.jeretina2@gmail.com; katja_krt@hotmail.com; andrej.starc@zf.uni-lj.si
}

\begin{abstract}
Introduction: Absenteeism is a phenomenon that describes absence at work and is measured as a frequency of missing days at work. It is directly related to consequences such as nursing staff shortage, low employees morale and disruptions in continuity of patient care. Causes of absenteeism are often attributed to mental disorders. In nursing manifestations of mental problems are often caused by the nature of work and working conditions. Methods: In this paper, a descriptive methodology with literature review in Slovenian and English language has been used. Union bibliographic database COBBISS and CINAHL, Medline (PubMed), Cochrane and Springerlink databases have been searched. Results: Many researchers have been studying risk factors which cause and/or influence the absenteeism in nursing. The causes for absenteeism are expected to be overload of work, excessive work demands and job dissatisfaction. Also, depression, anxiety and stress are expected to be recognized as the most frequent mental problems. Discussion: Based on previous findings guidelines for further research on mental health among nurses in Slovenia will be presented.

Key words: nurse, absence from work, mental health, job dissatisfaction
\end{abstract}

bsenteesim is a concept by which we define an absence of an employee
from the workplace and is measured with the frequency of missing wor-
king days. Experts estimate that the rate of absenteeism among heal-
th professionals is higher than in other professions. Therefore, identifying and
understanding the factors contributing to absenteeism is a particularly chal-
lenging for society (Waage and Bjorvatn, 2016). In addition to other factors, the
causes of absenteeism are often attributed to mental disorders (Lamont et al.,
2016; Perry et al., 2015). When absenteeism arises from mental health problems,
employees are usually absent for a longer period of time, and consequently this 
can lead to permanent incapacity for work (Anema et al., 2006). The very emergence of mental problems in nurses is in many cases the result of the nature of work and working conditions in health care (Mealer et al., 2007). The purpose of the paper is to present the specificity of absentism related to mental health in the field of nursing. The aim of the paper is to answer the following research questions: Is the level of absenteeism in the nursing profession higher compared to other professions? Which factors related to working place influence the frequency of absenteeism in nursing care? What is the impact of mental health on absenteeism in the nursing profession? What impact or consequences have mental health problems on the individual's ability to work in nursing profession?

\section{Methods}

The article used a descriptive method of work with a critical overview of Slovene and English professional and scientific literature. The literature search period took place from March to May 2017. The literature search was carried out using the Slovenian bibliographic-catalog database COBIB.SI and foreign CINAHL and Medline databases (PubMed). The search criteria used the language criterion, but we limited ourselves to articles published in both Slovenian and English. The applied keywords associated with the Boolean operator AND in English were: absenteeism AND mental disorders AND nursing, absenteeism AND health care, absenteeism AND nursing home, sickness absence AND health care, sickness absence AND mental health AND health care, mental health AND stress AND nursing. Slovene literature was searched with the following keywords: absentizem IN zdravstvena nega IN duševne motnje, absentizem IN depresija, bolniška odsotnost IN duševno zdravje IN zdravstvena nega. The result of keyword combinations is a different number of findings. The selected ones were about the risk factors that lead to absenteeism, the causes of mental health problems among health professionals and measures to improve mental health. The exclusion criteria were articles adressing the nursing students.

Table 1: English keyword combinations and number of findings.

\begin{tabular}{|c|c|c|c|c|c|c|}
\hline $\begin{array}{c}\text { Key words } \\
\text { (English) }\end{array}$ & $\begin{array}{c}\text { absenteeism } \\
\text { AND men- } \\
\text { tal disorders } \\
\text { AND nurs- } \\
\text { ing }\end{array}$ & $\begin{array}{l}\text { absenteeism } \\
\text { AND men- } \\
\text { tal disorders } \\
\text { AND nurs- } \\
\quad \text { ing }\end{array}$ & $\begin{array}{c}\text { absenteeism } \\
\text { AND nursing } \\
\text { home }\end{array}$ & $\begin{array}{l}\text { sickness ab- } \\
\text { sence AND } \\
\text { health care }\end{array}$ & $\begin{array}{c}\text { sickness ab- } \\
\text { sence AND } \\
\text { mental health } \\
\text { AND health } \\
\text { care }\end{array}$ & $\begin{array}{c}\text { mental } \\
\text { health AND } \\
\text { stress AND } \\
\text { nursing }\end{array}$ \\
\hline Search results & 15 & 49 & 64 & 104 & 13 & 112 \\
\hline Used articles & 5 & 2 & $\mathrm{o}$ & 1 & 4 & 2 \\
\hline
\end{tabular}




\begin{tabular}{lccc}
$\begin{array}{c}\text { Keywords } \\
\text { (Slovene) }\end{array}$ & $\begin{array}{c}\text { absentizem IN zdravstvena } \\
\text { nega IN duševne motnje }\end{array}$ & absentizem IN depresija & $\begin{array}{c}\text { bolniška odsotnost IN } \\
\text { duševno zdravje IN zdravst- } \\
\text { vena nega }\end{array}$ \\
\hline Search results & 6 & 2 & 2 \\
\hline Used articles & $\mathrm{o}$ & $\mathbf{1}$ & $\mathrm{0}$ \\
\hline
\end{tabular}

\section{Results}

Health absenteeism is a serious social problem with many causes and consequences. The consequences of absenteeism are present in the case of employees (lower income, lower prospects, job dissatisfaction, loss of working habits), employers (costs for compensation, costs for substitute workers, lower productivity) and at the level of the national economy as a whole (lower gross domestic product) (Vučković, 2010). On the basis of national data from Canada, it is estimated that, on average, there are up to 1.5 times more probability for absenteeism among health professionals than for other professions (Lamont et al., 2016).

Perry and colleagues (2015) studied the mental health of nurses through a cross-sectional study. From the 382 employees, almost $14 \%$ excluded that they have already been diagnosed with mental disorders such as anxiety and depression in the past. $6 \%$ of nurses state that they are currently using psychoactive drugs. The researchers also found the presence of other symptoms that are potentially related to mental health, such as: headache, fatigue, dyspepsia, night sweating, sleeping problems and palpitations.

The impact of mental health on health and productivity of the working population has been underestimated for a long time. The United Kindom Department of Health estimates that $15-30 \%$ of people will have mental health problems during their working lives, which are one of the leading causes of morbidity. Mental problems among employees do not only have consequences for the individual, but also affect the productivity of the company, as they lead to work failure, workplace accidents, absenteeism and employee fluctuation (Harnois and Gabriel, 200o).

The nursing profession is an emotionally and physically demanding occupation and research suggests that working as a nurse means a high risk of experiencing stress, anxiety, and depression. Authors often report the presence of mental illness, drug abuse, workplace aggression, stress and burnout in nursing care. Mental disorders and burnout are often the result of working, organizational and personal factors (Perry et al., 2015).

Researchers from Australia have studied the link between mental health, workplace characteristics and absence from work among nurses and midwives through a cross-sectional study. The survey included 5041 people. They found that the factors related to mental health that contributed to absenteeism among nurses and midwives are: starting a career, multiple work, demanding work, abuse at work, smoking, symptoms of mental disorders, desire for cancellation, 
use of psychotropic medicines and insomnia. The authors state that on the basis of findings on the connection of mental health with absenteeism in health care system, the specific characteristics of employees could be used as indicators for the early identification of individuals who are at risk of absenteeism (Lamont et al., 2016).

There is consensus among experts on the correlation of unfavorable working conditions with the morbidity of the working population. In nursing practice, such unfavorable working conditions include: an intensive working pace, a shortage of human resources and materials, pressure from superiors, low income, a two- or three-shift work system, exhaustion as a result of multishifts work and frequent interactions with severe, usually terminal patients (Santana et al., 2016). The nurses' mental health is particularly affected by work environments where employees lack work autonomy, where they experience low levels of support and few opportunities to acquire new knowledge, where a high degree of emotional exhaustion and the occurrence of physical burnout prevail, and where employees have poor sleep habits due to multishift work. Mental health consequences are seen in nurses who are under the influence of high expectations and are in conflict working relationships and work in an environment where there is a high mortality rate of patients and a high possibility of traumatic events. All these factors have a major negative impact on productivity, absenteeism and presentism, work performance, patient care and patient satisfaction (Perry et al., 2015).

The authors found out that high work demands are associated with emotional exhaustion, anxiety, depression, and dissatisfaction with work. The ability to control the working environment and social support positively influence the well-being and work satisfaction of nurses and decrease the symptoms of psychological distress and emotional exhaustion. High work demands, through the impact on the employees' health increase level of absenteeism (Roelen et al., 2012).

Clausen and colleagues (2011), through longitudinal research, found out that high working demands are strongly linked to absenteeism in the case of elderly health care providers. On the other hand, positive sources in the workplace, such as the possibility of influencing on work, higher quality of management and a positive team climate protect individuals from morbidity and consequently reduce the amount of absenteeism. Roelen and colleagues (2012) add that in addition to all other factors, also the way in which employees are faced with the disease, affects sick leave. It is therefore a phenomenon that arises as a result of the interaction between the personality characteristics, working conditions and the socio-cultural environment.

The concern for the health of nurses, the identification of risk factors and mental illnesses is not only important for ensuring the quality of life of nurses in general, but also for maintaining competence that leads to quality treatment for patients. Suzuki and colleagues (2005) showed the impact of accidents at work (eg. needle injury) on the development of mental disorders and 
sleep disorders. Xiong and colleagues (2017) investigated whether the injection needle injury affected the development of a mental disorder. There were 302 nurses involved, 162 of them had already had needle injury before. The development of mental illness was almost twice as likely for nurses exposed to work with blood as in those who were not exposed to work with blood. Also physical symptoms and symptoms of social dysfunction, anxiety and depression were more frequently expressed among nurses exposed to work with blood. It is necessary to provide appropriate psychological support for the stress relief at the workplace.

Absenteesim in nursing represents a major economic problem both for the organization and for a personal problem for the individual. Long-term absence can cause many negative consequences, such as exclusion from the workplace and, consequently, social isolation in poverty, therefore recognizing the risk factors for predicting absence from work is very important (Roelen et al., 2015; Roelen et al., 2013).

\section{Discussion}

The average sick leave for a healthcare professional ranges from 12 to 15 days per year per person (Lamont et al., 2016). Waage in Bjorvatna (2016) also points out that absenteeism is more frequent among healthcare workers as a result of illness compared to workers in other sectors. Many authors (Mao et al, 2016; Gaudine et al., 2011) note that the rate of absence from all professions is the highest in the field of nursing care.

Lack of employee support, working influences, organizational climate and the ambiguity of the role are associated with the emergence of psychological problems in nurses. The most common source of poor mental health is workload pressure (Petterson et al., 1995). The hardship caused by the small role in decision-making, low social support at the workplace, and pressures by leaders are linked both to anxiety and to depression (Quine, 1999).

To protect and maintain the mental health of nurses and to ensure safe, effective and quality patient care, targeted stress relief measures are required (Caufigld et al, 2004). Many authors work on the development of strategies for reducing stress among nurses. Some approaches address the problem at the level of the individual, others at the level of the organization, and the authors also discuss the combination of both. Mc Vicar (2003) points out that effective approaches ensure better safety and health outcomes of healthcare professionals, leading to safe, efficient and quality patient care, and ultimately reducing the economic effects of stress in hospitals, industry and the economy. Deckro and colleagues (2002) represent a program that focuses on an individual in a way to improve the individual's ability to successfully meet challenging situations at work by educating about the source of stress and the impact on health, and also acquiring skills and abilities to reduce stress (eg adequate time allocation, relaxation methods). The effects of the program have been shown to redu- 
ce the symptoms of stress, anxiety and sleep disorders, and positive physical, mental and emotional changes. Implementation of this type of program is not demanding and does not require a financial contribution.

On the contrary to programs operating on an individual level, interventions at the organization level are focused on reducing stressful working conditions. Examples of such interventions include the transformation of jobs, clear definition of job descriptions, the formation of joint staff committees, and the leadership, which increases the involvement of workers and gives them the opportunity to participate in decision-making (Murphy, 1999). As well as programs on an individual level, it is also necessary to adjust organizational adjustments according to a particular job position. The manager can, in cooperation with an expert, diagnose the situation at the level of work units and organization. On the basis of the state of the situation, approaches to prevent or eliminate harmful conditions begin to develop. Such measures include changes in employment according to staff needs, adjustment of working time or shi$\mathrm{fts}$, inclusion of breaks for rest and ensuring an optimal balance of workloads (Roberts et al., 2013).

\section{Conclusion}

Despite numerous studies and analyzes of the phenomenon of absenteeism, there are still insufficient studies of its direct association with mental illnesses in the nursing profession. It is difficult to define causal and consequential connections between mental disorders and absentism. Even long-term unplanned absenteeism due to serious illness can affect the mental health of a nurse, since longer absenteeism means lower incomes and reduced competence at work. According to the findings of many researchers, absenteeism among nurses is influenced by many different factors, usually a combination of the characteristics of the working environment and personality traits of an individual. It would be sensible to study and analyze the causes of absenteeism in nurses in Slovenia and to compare the results between hospitals and other health institutions of different provincial regions.

\section{References}

ANEMA, J.R., JETTINGHOFF, K., HOUTMAN, L.D, SCHOEMAKER, C.G., BUIJS, P.C. in VAN DEN BERG, R., 2006. Medical care of employees long-term sick listed due to mental health problems: a cohort study to describe and compare the care of the occupational physician and the general practitioner. Journal of occupational rehabilitation, letn. 16, št. 1, str. 41-52.

BEGAT, I., ELLEFSEN, B. in SEVERINSSON, E., 2005. Nurses' satisfaction with their work environment and the outcomes of clinical nursing supervision on nurses' experiences of well- being-a Norwegian study. Journal of Nursing Management, letn. 13, št. 3, str. 221-230. 
CAUlfield, N., CHANG, D., DOLlARD, M. in ELSHAUG, C., 2004. A review of occupational stress interventions in Australia. International Journal of Stress Management, letn. 11, št. 2, str. 149-166.

CLAUSEN, T., NIELSEN, K., GOMES CARNEIRO, I. in BORG, V., 2011. Job demands, job resources and long-term sickness absence in the Danish eldercare services: a prospective analysis of register-based outcomes. Journal of Advanced Nursing, letn. 68, št. 1, str. 127-136.

DECKRO, G.R., BALLINGER, K.M., HOYT, M., WILCHER, M., DUSEK, J., MYERS, P., GREENBERG, B., ROSENTHAL, D.S. in BENSON, H., 2002. The evaluation of a mind/body intervention to reduce psychological distress and perceived stress in college students. Journal of American College Health, letn. 50, št. 6, str. 281-287.

GAUDINE, A., SAKS, A.M., DAWE, D. in BEATON, M., 2011. Effects of absenteeism feedback and goal-setting interventions on nurses fairness perceptions, discomfort feelings and absenteeism. Journal of nursing management, letn. 21, št. 3, str. 591-602.

HARNOIS, G. in GABRIEL, P., 200o. Mental health and work: impact, issues and good practices. World Health Organization. Geneva, str. 1-4.

ISHIKAWA, H., KAWAKAMI, N. in KESSLER, R.C., 2016. Lifetime and 12-month prevalence, severity and unmet need for treatment of common mental disorders in Japan: results from the final dataset of World Mental Health Japan Survey. Epidemiology and Psychiatric Sciences, letn. 25, št. 3, str. 217-229.

JENKINS, R. in ELLIOTT, P., 2004. Stressors, burnout and social support: nurses in acute mental health settings. Journal of Advanced Nursing, letn. 48 , št. 6 , str. $622-631$.

LAMONT, S., BRUNERO, S., PERRY, L., DUFFIELD, C., SIBBRITT, D., GALLAGHER, R. in NICHOLLS, R., 2016. "Mental health day" sickness absence amongst nurses and midwives: workplace, workforce, psychosocial and health characteristics. Journal of advanced nursing, letn. 73, št. 5, str. $1172-1181$.

LIMA SANTANA, L., MANSANO SARQUISB, L.M., D'ALMEIDA MIRANDA, M.F. in ANDRES FELLIC, V.E., 2016. Absenteeism due to mental disorders in health professionals at a hospital in southern Brazil. Revista gaúcha de enfermagem, letn. 37, št. 1, str. 1-8.

MAO, F.Q., ZHANG, P., LI, J., WANG, X.M., ZOU, H., GAO, L., YANG, J.H in LI, J.T., 2006. A case-control study on the risk factors of chronic fatigue syndrome in doctors and nurses. Chinese journal of behavioral medical science, letn. 15, št. 4, str. 355-357.

McVICAR, A., 2003. Workplace stress in nursing: a literature review. Journal of Advanced Nursing, letn. 44, št. 6, str. 633-642. 
MEALER, M.L., SHELTON, A., BERG, B., ROTHBAUM, B., in MOSS, M., 2007. Increased prevalence of post-traumatic stress disorder symptoms in critical care nurses. American journal of respiratory and critical care medicine, letn. 175, št. 7, str. 693-697.

MURPHY, L.R., 1999. Organisational interventions to reduce stress in health care professionals. In: FRITH-COZENS, J. in PAYNE, R.L., eds. Stress in health professionals: Psychological and organisational causes and interventions. Chichester: John Wiley \& Sons, pp. 149-162.

PERRY, L., LAMONT, S., BRUNERO, S., GALLAGHER, R. in DUFFIELD, C., 2015. The mental health of nurses in acute teaching hospital settings: a cross-sectional survey. BMC Nursing, letn. 14, št. 15, str. 1-8.

PETTERSON, I.-L., ARNETZ, B.B. in ARNETZ, J.E., 1995. Predictors of Job Satisfaction and Job Influence - Results from a National Sample of Swedish Nurses. Psychother Psychosom, letn. 64, št. 1, str. 9-19.

QUINE, L., 1999. Workplace bullying in NHS community trust: staff questionnaire survey. BMJ, letn. 318, št. 7178, str. 228-232.

ROBERTS, R.K. in GRUBB, P.L., 2014. The Consequences of Nursing Stress and Need for Integrated Solutions. Rehabilitation Nursing, letn. 39, št. 2, str. 62-69.

ROELEN, C., van RHENEN, W., SCHAUFELI, W., van der KLINK, J., MAGERØY, N., MOEN, B., BJORVATN, B. in PALLESEN, S., 2013. Mental and physical health-related functioning mediates between psychological job demands and sickness absence among nurses. The journal of advanced nursing, letn. 70, št. 8, str. 1780-1792.

ROELEN, C.A., van RHENEN, W., GROOTHOFF, J.W., van der KLINK, J.J., ITMANN, U.B. in HEYMANS, M.W., 2012. The development and validation of two prediction models to identify employees at risk of high sickness absence. European journal of public health, letn. 23, št. 1, str. 128-133.

ROELEN, C.A.M., HEYMANS, M.W., TWISK, J.W.R., van RHENEN, W., PALLESEN, S., BJORVATN, B., MOEN, B.E. in MAGERØY, N., 2015. Updating and prospective validation of a prognostic model for high sickness absence. International archives of occupational and environmental health, letn. 88, št. 1, str. 113-122.

SUZUKI, K., OHIDA, T., KANEITA, Y., YOKOYAMA, E. in UCHIYAMA, M., 2005. Daytime sleepiness, sleep habits and occupational accidents among hospital nurses. Journal of Advanced Nursing, letn. 52, št. 4, str. 445-453.

VUČKOVIĆ, R., 2010. Obvladovanje zdravstvenega absentizma - izziv za družbo. V: KOS, D., ur. Zdravstveni absentizem v sloveniji. Zbornik primerov iz prakse 14 slovenskih podjetij. Ljubljana: Zavod za zdravstveno zavarovanje Slovenije, str. 10-20. 
WAAGE, S. in BJORVATN, B., 2017. Health, psychosocial and workplace characteristics may identify nurses and midwives at risk of high absenteeism. Evidence-based nursing, letn. o, št. o, str. 1-2.

WILSON, G.B., 2001. Safer handling practice for nurses: a review of the literature. British Journal of Nursing, letn. 10, št. 2, str. 108-114.

XIONG, X., LI, M., JIANG, Y., TONG, X. in PENG, Y., 2017. Study of blood exposure-related mental health illness among clinical nurses. Frontiers of Medicine, letn. 11, št. 1, str. 147-151. 